\title{
Simulation of District Cooling Plant and Efficient Energy Air Cooled Condensers (Part I)
}

\author{
Mousa M. Mohamed', Mohammed Hueesin Almarshadi² \\ ${ }^{1}$ Mechanical Power Engineering, Faculty of Engineering, Menoufia University Shebin El kom, Egypt \\ ${ }^{2}$ Arid Land Agriculture Department, Faculty of Meteorology, Environment and Arid Land Agriculture, King Abdulaziz \\ University, Jeddah, KSA \\ Email:mousamohamed@yahoo.com,malmarshadi@kau.edu.sa
}

How to cite this paper: Mohamed, M.M. and Almarshadi, M.H. (2017) Simulation of District Cooling Plant and Efficient Energy Air Cooled Condensers (Part I). Journal of Electronics Cooling and Thermal Control, 7, 45-62.

https://doi.org/10.4236/jectc.2017.73005

Received: May 18, 2017

Accepted: July 18, 2017

Published: July 21, 2017

Copyright (C) 2017 by authors and Scientific Research Publishing Inc. This work is licensed under the Creative Commons Attribution International License (CC BY 4.0).

http://creativecommons.org/licenses/by/4.0/

\section{Open Access}

\begin{abstract}
In hot arid countries with severe weather, the summer air conditioning systems consume much electrical power at peak period. Shifting the loads peak to off-peak period with thermal storage is recommended. Model A of residential buildings and Model B of schools and hospitals were used to estimate the daily cooling load profile in Makkah, Saudi Arabia at latitude of $21.42^{\circ} \mathrm{N}$ and longitude of $39.83^{\circ} \mathrm{E}$. Model A was constructed from common materials, but Model B as Model A with $5-8 \mathrm{~cm}$ thermal insulation and double layers glass windows. The average data of Makkah weather through 2010, 2011 and 2012 were used to calculate the cooling load profile and performance of air conditioning systems. The maximum cooling load was calculated at 15:00 o'clock for a main floor building to a 40-floor of residential building and to 5 floors of schools. A district cooling plant of 180,000 Refrigeration Ton was suggested to serve the Gabal Al Sharashf area in the central zone of Makkah. A thermal storage system to store the excess cooling capacity was used. Air cooled condensers were used in the analysis of chiller refrigeration cycle. The operating cost was mainly a function of electrical energy consumption. Fixed electricity tariff was $0.04 \$ / \mathrm{kWh}$ for electromechanical counter, and 0.027, 0.04, 0.069 $\$ / \mathrm{kWh}$ for shifting loads peak for the smart digital counter. The results showed that the daily savings in consumed power are $8.27 \%$ in spring, $6.86 \%$ in summer, $8.81 \%$ in autumn, and $14.55 \%$ in winter. Also, the daily savings in electricity bills are $12.26 \%$ in spring, $16.66 \%$ in summer, $12.84 \%$ in autumn, and $14.55 \%$ in winter. The obtained maximum saving in consumed power is $14.5 \%$ and the daily saving in electricity bills is $43 \%$ in summer when the loads peak is completely shifted to off-peak period.
\end{abstract}

\section{Keywords}

District Cooling, Thermal Storage System, Cooling Load Profile, Refrigeration 
Capacity, Shifting Loadspeak, Saving in Electricity Bills, Saving Power, Efficient Energy

\section{Introduction}

In recent years, hot weather countries and areas like Qatar, UAE, Saudi Arabia, Singapore, Malaysia and Hong-Kong have installed a large scale district cooling plant. At the same time, other hot weather countries are the potential followers of such networks, while installation of centralized chiller plants for individual buildings is already a trend [1]. District cooling system uses thermal energy in the form of chilled water from a central plant to multiple buildings through a distribution network of underground insulated pipes for use in space cooling. The cooling process takes place in the central plant which eliminates the use of separate conventional cooling system from each building. The district cooling plant primarily consists of three components namely, the central cooling system, the distribution network and the energy transfer buildings [2]. The cooling equipment, cooling towers, power generation and thermal storage system are the main components of a central cooling system. The distribution system is insulated pips network that transfers the cooling medium or chilled water from the central cooling system to different energy transfer buildings. The energy transfer buildings contain indoor heat exchanger, secondary pumping system, chilled water piping and other auxiliary equipments.

A large-scale of district cooling plant could save energy consumption costs from $25 \%$ to $40 \%$ as compared with the sum of conventional centralized airconditioning system of each building. In addition to a better energy efficiency, there are other environmental and planning benefits such as, reduced water consumption, reduced carbon footprint, minimized noise and vibration impact, flexibility in building design, saving in plant room space, reduced operating redundancy and enhanced system reliability [3] [4]. District cooling plant supplies cooling services at the temperature level of $5^{\circ} \mathrm{C}-7^{\circ} \mathrm{C}$, while with an expected return temperature of $12^{\circ} \mathrm{C}-15^{\circ} \mathrm{C}$. The central cooling plant is mostly assisted with a cold thermal storage unit, which allows the leveling of the cooling loads in the network during the day or season and creates a match in supply and demand of cooling services [5] [6]. Thus, a district cooling network with $8^{\circ} \mathrm{C}$ and $15^{\circ} \mathrm{C}$ as the supply-return temperature should be an ideal one. Positive to this configuration is lower energy loss and higher system efficiency. The energy use in a large district cooling plant before and after the addition of stratified chilled-water storage has been conducted and the average efficiency of the system improved by more than $10 \%[7]$.

The chilled water storage system has been constructed and is fully operational. The system is the largest stratified chilled water storage and the first to transfer the full air conditioning load to off-peak in Australia. The system gives approx- 
imately $45 \%$ total spare capacity in its current system [8]. The optimal energy dispatch of an ice storage air-conditioning system has been simulated on a real air-conditioning system [9]. The data including the return temperature of chilled water, the supply temperature of chilled water, the return temperature of ice storage, and the supply temperature of ice storage are measured. The leastsquares regression is used to obtain the input-output curve for the cooling load and power consumption of chillers and ice storage tank. The electricity savings on a summer day and on a non-summer day are $2.89 \%$ and $8.25 \%$, respectively.

Therefore, the application of thermal energy storage has gained attractively to reduce energy cost. Many attractive tariff packages are being offered by the electricity provider to promote thermal energy storage. The tariff packages offered higher cost of electricity during peak period and lower cost of electricity during off-peak period. The results showed the energy required for running air condition unit and with of thermal energy storage. There are $36.5 \%-37.82 \%$ total energy powers saving during peak period and this power saving manages to reduce maximum demand charge. Also, from the economic analysis conducted, it is found that the initial investment will recover in 5.41 years and is considered as a good investment whereby the initial cost is recovered less than 7 years [10].

The objective of the present study is to investigate the effect of hourly and seasonal environmental conditions, the building cooling load profile on the performance of refrigeration cycle and consumed power. The shifting of consumed power of the refrigeration capacity demand at peak to off-peak period with thermal storage system is proposed. The electric cost savings of consumed power with tariff packages are being offered by the electricity provider to promote the thermal storage system. Air cooled condensers for chillers refrigeration cycle are used to examine the daily power consumption and the reduction cost of electricity bills.

\section{Building Models}

The building cooling load is calculated according to the building specification and construction materials. Figure 1 shows the layout of two types of buildings, the first is residential buildings and hotels; the second is schools and governmental buildings. Two Models A and B were used for the two types of buildings.

The buildings Model A is constructed from common materials; hollow bricks, heavy concrete, single layer glazed windows, and wooden doors as illustrated in Figure 2, but the buildings Model Bistypical as Model A of construction materials in addition of $5-8 \mathrm{~cm}$ thermal insulation of $0.039 \mathrm{~W} / \mathrm{m} \cdot \mathrm{K}$ in outside walls, floor, ceiling and glazed windows with double layers of air gab $1-3 \mathrm{~cm}$. The peak or maximum building heat load is estimated at 3 o'clock PM for outside condition of $45^{\circ} \mathrm{C}$ dry bulb and $28^{\circ} \mathrm{C}$ wet bulb and inside condition of $24^{\circ} \mathrm{C}$ dry bulb and $50 \%$ relative humidity.

The building heat load is the amount of heat removed or added to the conditioned space to maintain the thermal comfort. The building heat load is divided 


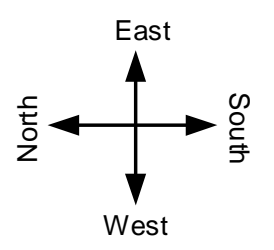

\section{Residential Buildings and Hotels}

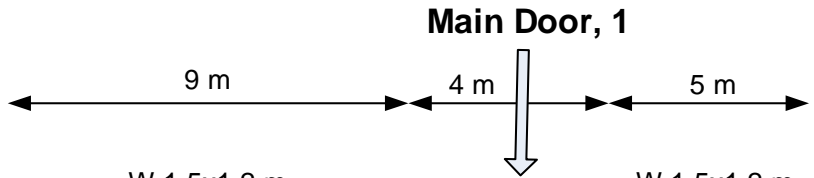

ocation of Makkah

Latitude, $21.42^{\circ}$

Longitude, $39.83^{\circ}$

Summer season

Dry bulb temperature $45^{\circ} \mathrm{C}$

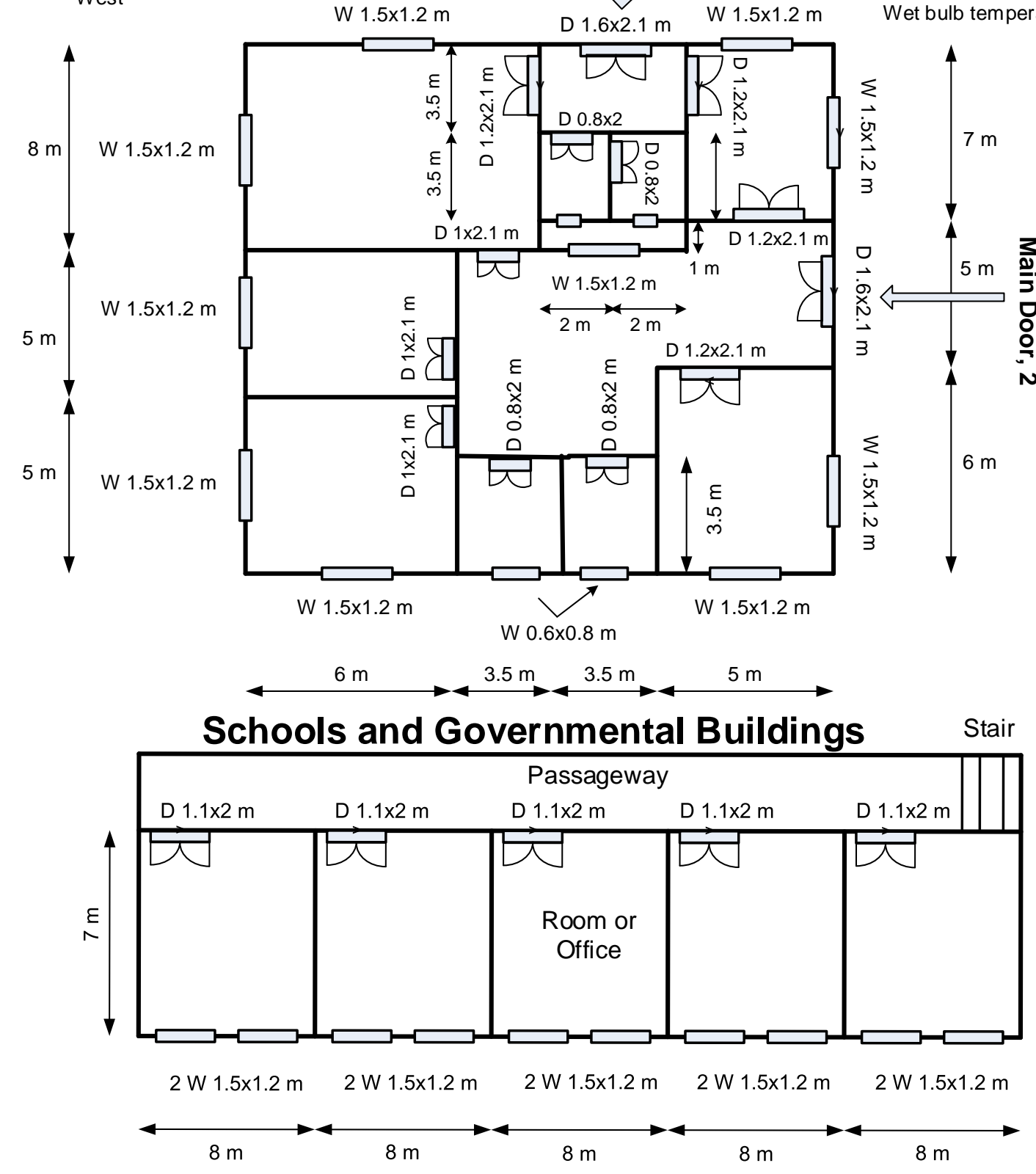

D $1.6 \times 2.1 \mathrm{~m}$

W $1.5 \times 1.2 \mathrm{~m}$

Wet bulb temperature $24^{\circ} \mathrm{C}$

Figure 1. Layout residence buildings and schools.

in two heat loads, the first heat load is the sensible heat load which is a function of temperature difference between outside and inside condition, and radiation heat through glazing windows. The second heat load is the latent heat load which is a function of humidity ratio difference between outside and inside condition, and moisture content of conditioned space. The building heat load in 


\section{Model B}

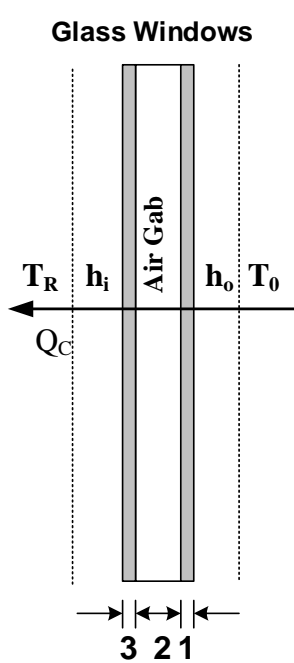

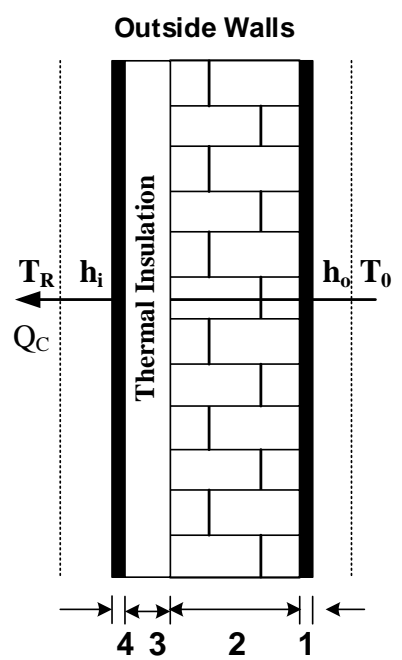

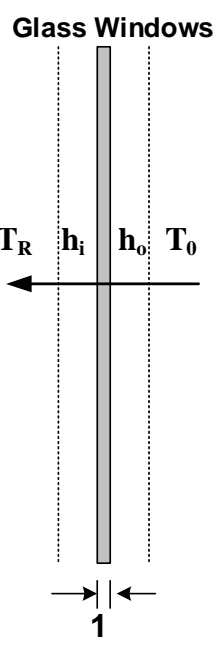

Model A

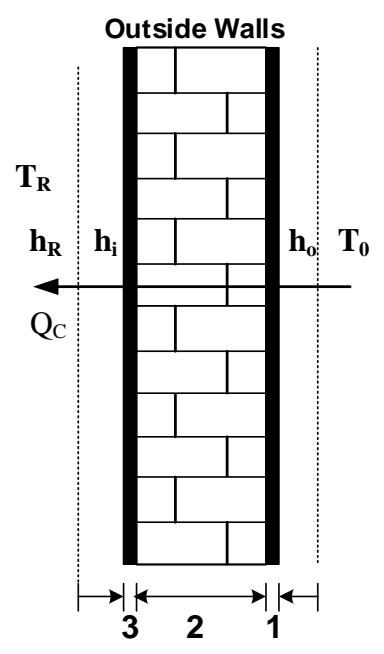

Figure 2. Building Models A and B with common construction materials and thermal insulation.

summer is the summation of external and internal heat loads. But, the building heat load in winter is the difference between the external and internal heat loads. The building cooling load in summer is calculated using appropriate cooling load temperature difference, CLTD method [11]. A computer program is prepared and examined. The data needed according to CLTD method for outside environment and building specification are inserted as subroutine to get the final results of hourly building cooling load.

The building cooling load of two Models A and B, are estimated as a floor area to Ton of Refrigeration from 1 to 40 floors for residence buildings and hotels, and from 1 to 5 floors for schools and government buildings. For buildings Model A and B, Figures 3-6 show the required floor area of conditioned space to Ton of Refrigeration and percentage of saving in cooling load. It is observed that for main floor, 1 Ton of Refrigeration is enough to $16 \mathrm{~m}^{2}$ of floor area for residence buildings and hotels of Model A and $21 \mathrm{~m}^{2}$ of Model B, and these values increased gradually with floors number until 25 floors as shown in Figure 3. The saving in cooling load of Model A to Model B for residence buildings and hotels is $25 \%$ for main floor and 55\% for 25 floors as illustrated in Figure 4. For schools and government buildings, the 1 Ton of Refrigeration is enough to 7.5 $\mathrm{m}^{2}$ of floor area for main floor of Model A and $10 \mathrm{~m}^{2}$ for main floor of Model B, and significant increase until 5 floors is observed as shown in Figure 5. The saving in cooling load of Model A to Model B for schools and government buildings is 34\% for main floor and 45\% for 5 floors as illustrated in Figure 6. Substantial increase in floor area, $\mathrm{m}^{2} / \mathrm{TR}$ until 10 floors for residence buildings and 4 floors for schools are observed.

\section{Building Cooling Load Profile}

Makkah weather data for years, 2010, 2011, and 2012 at 21 day for each month 
Residence Buildings and Hotels

- Model B with $5 \mathrm{~cm}$ Insulation and Doubl Glass Layers

$\rightarrow-M o d e l$ A Common structure Material without Insulation

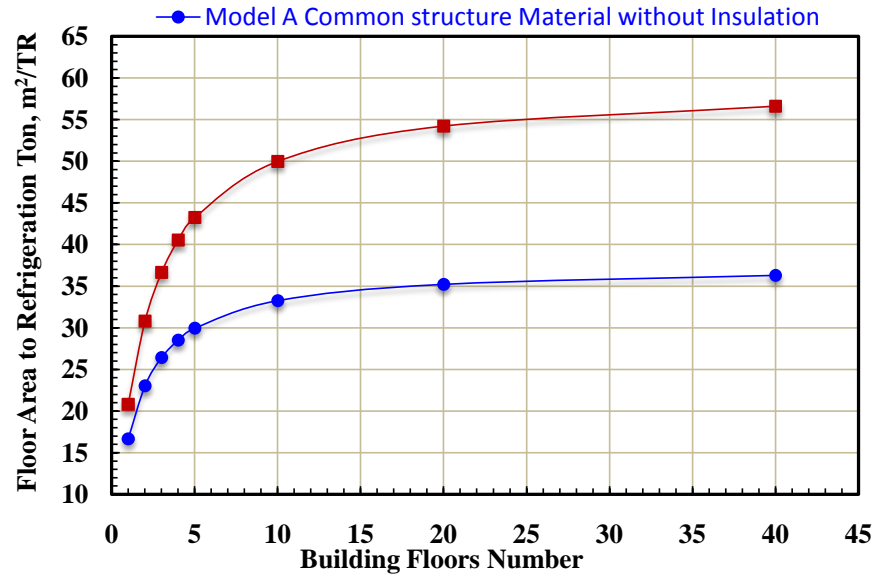

Figure 3. Floor area $\mathrm{m}^{2} / \mathrm{TR}$ for residence buildings and hotels.

Residence Buildings and Hotels

- - Saving in Cooling Load of Building Model B to Model A

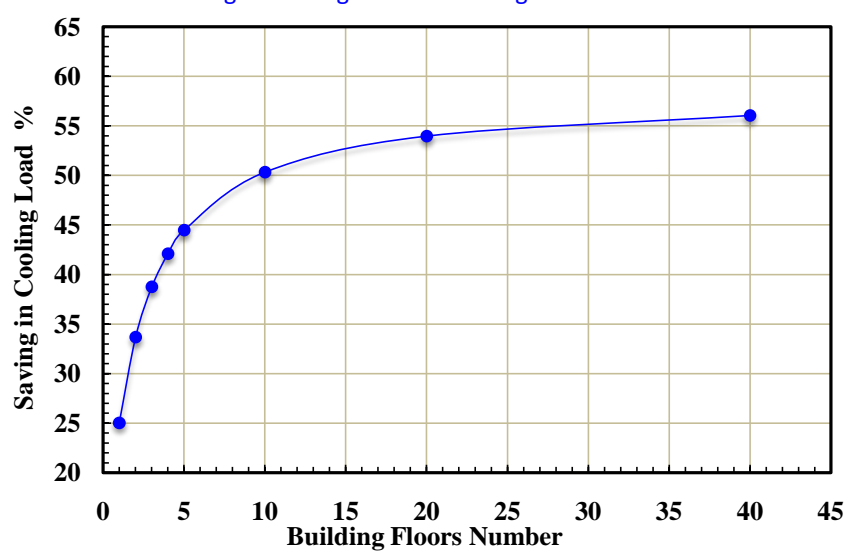

Figure 4. Percentage saving in cooling load for residence buildings and hotels.

Schools and Government Buildings

$\rightarrow$ Model B with $5 \mathrm{~cm}$ Insulation and Doubl Glass Layers

- Model A Common structure Material without Insulation

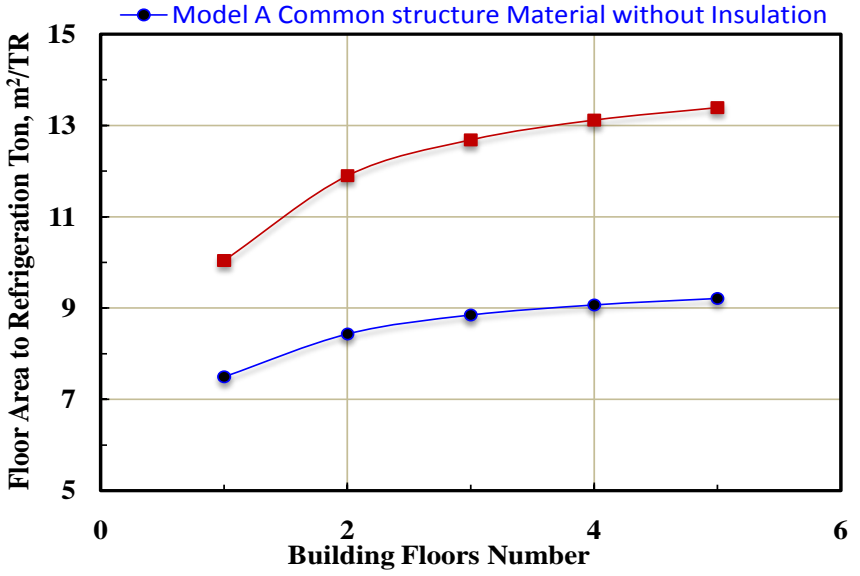

Figure 5. Floor area $\mathrm{m}^{2} / \mathrm{TR}$ for schools and government buildings. 
are imported from meteorological station. The average data of dry bulb temperature, dew point temperature, and relative humidity for each season are estimated and illustrated in Figure 7 and Figure 8. The dry bulb temperature is increased hourly from sunrise to maximum value at 15:00 o'clock and decreased to initial value at night as shown in Figure 7. Opposite the trend of dry bulb temperature, the relative humidity decreased from sunrise to minimum value at 15:00 o'clock and increased to maximum value at night as shown in Figure 8. The building cooling load profile during four seasons, spring, summer, autumn, and winter are calculated and illustrated in Figure 9. The maximum building cooling load was happened at 16 o'clock. The cooling load profile in spring and

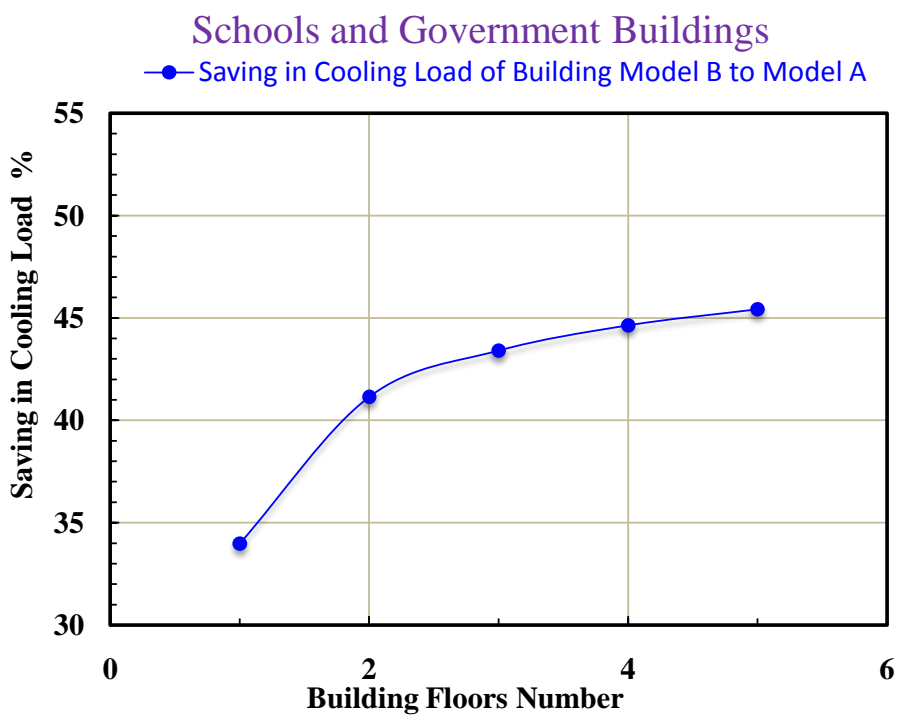

Figure 6. Save in cooling load for schools and government buildings.

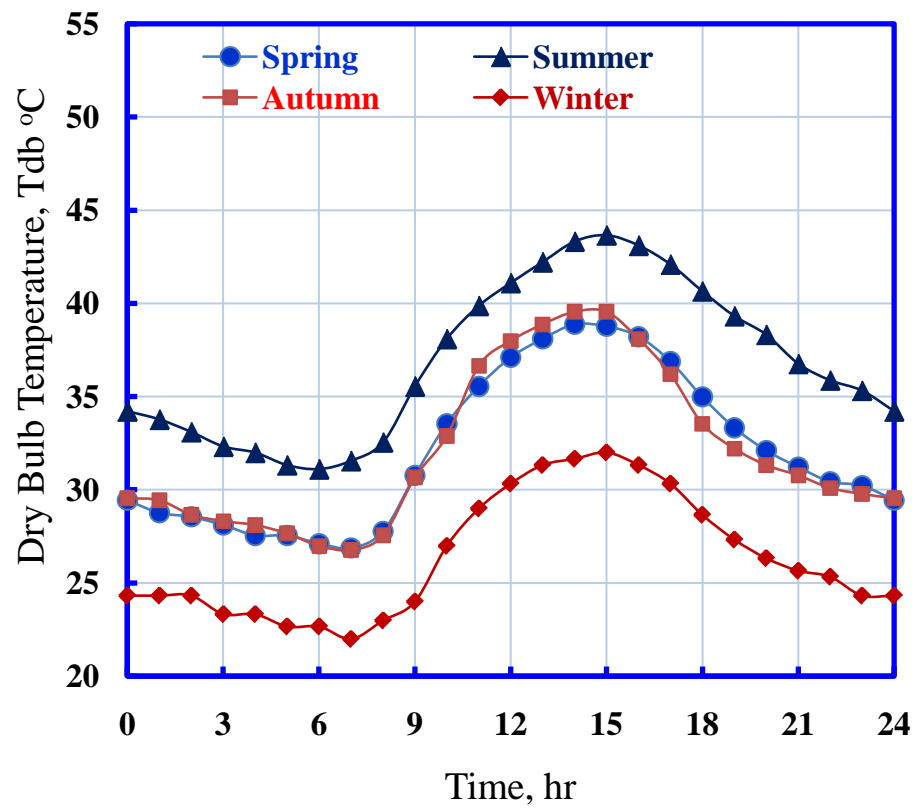

Figure 7. Average of dry bulb temperature. 


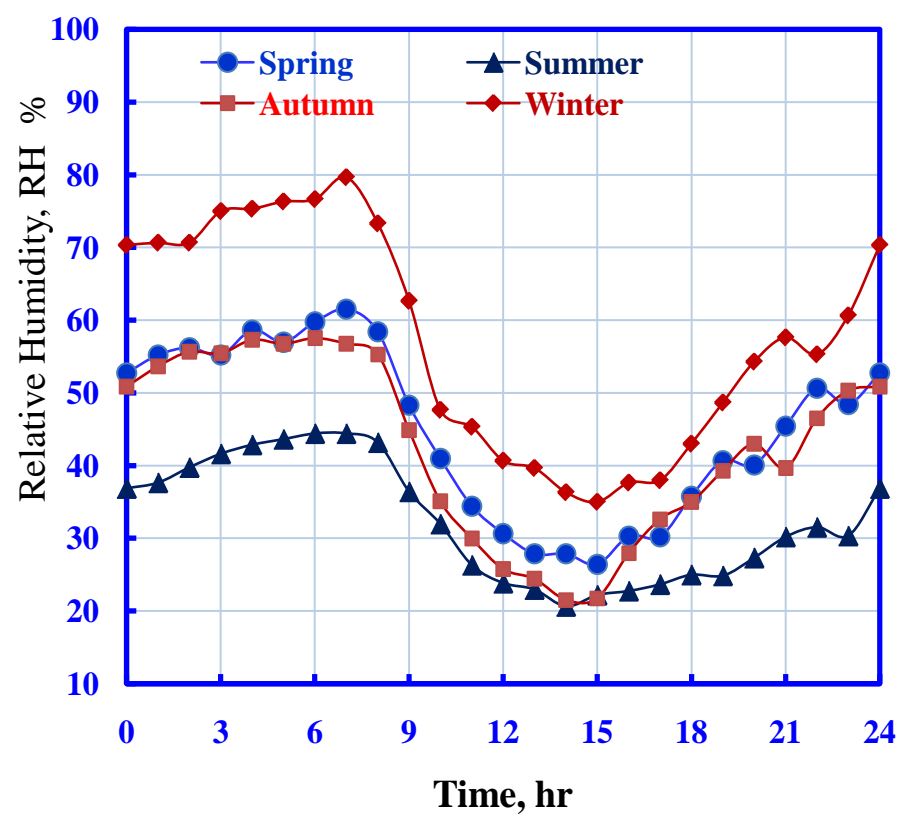

Figure 8. Average of relative humidity.

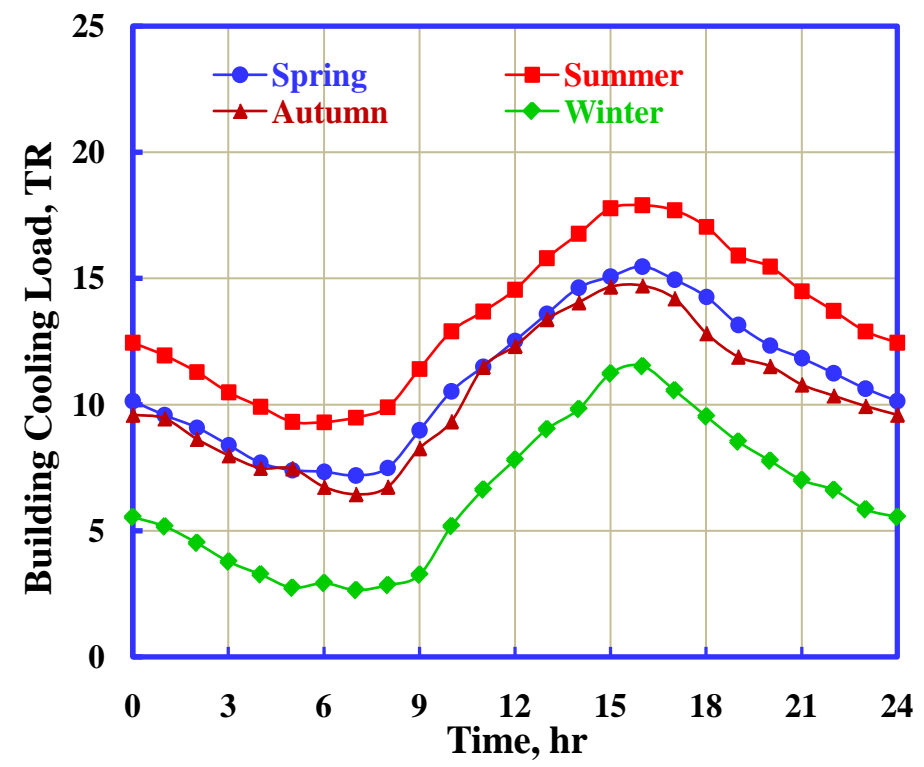

Figure 9. Building cooling load profile.

autumn is the same trend with small difference. The hourly building cooling load was divided on the maximum value at 16 o'clock to get the trend ratio of demand cooling load for simulation the hourly cooling load for district cooling plant as shown in Figure 10.

\section{Refrigeration Capacity Analysis}

A compression refrigeration machine with air cooled condenser is proposed. A simple refrigeration cycle is assumed with constant evaporating temperature of $-1^{\circ} \mathrm{C}$ and condensing temperature of 10 degrees above outside dry bulb temper 
ature. The compression process with $80 \%$ isentropic efficiency is assumed and pressure drop of 0.5 bar in suction and delivery lines is appointed. The superheating temperature is $1^{\circ} \mathrm{C}$ in suction line and sub-cooled temperature is $5^{\circ} \mathrm{C}$ in liquid line. The CoolPack program [12] is used in the analysis of refrigeration cycle to estimate the Coefficient of Performance, COP, and compressor consumed power. The Makkah weather is hot and dry in summer through the daytime. The coefficient of performance, COP, of the refrigeration machine with air cooled condenser is very sensitive to the hourly change of outside air temperature. The COP is inversely proportional with the outside air temperature as shown in Figure 11. So, the COP of refrigeration cycle is much better during night than daytime. So, the operation of refrigeration machine after sunset to sunrise is much economical because the compressor consumes less power.

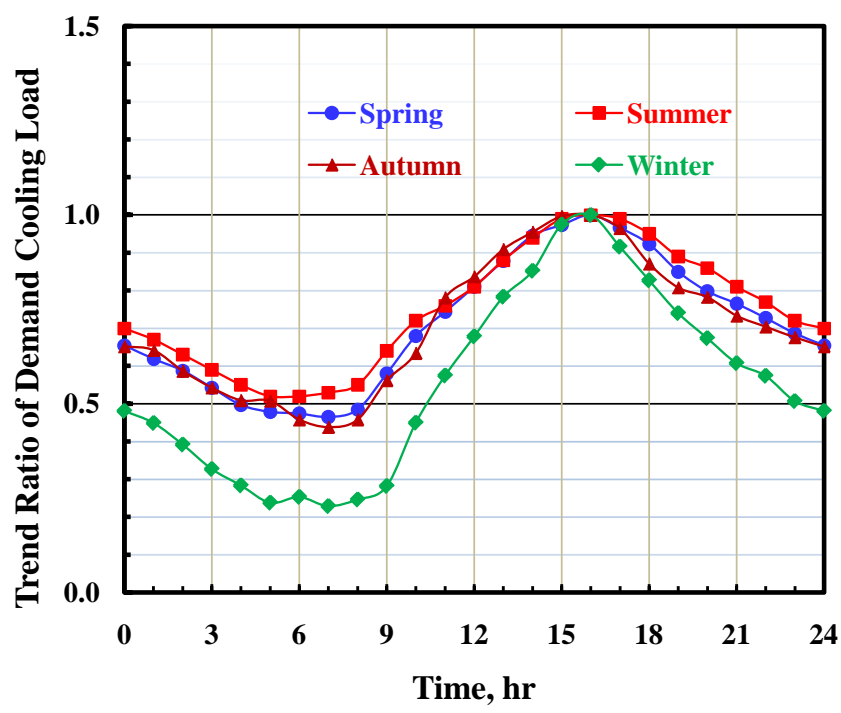

Figure 10. Trend ratio of demand cooling load to maximum.

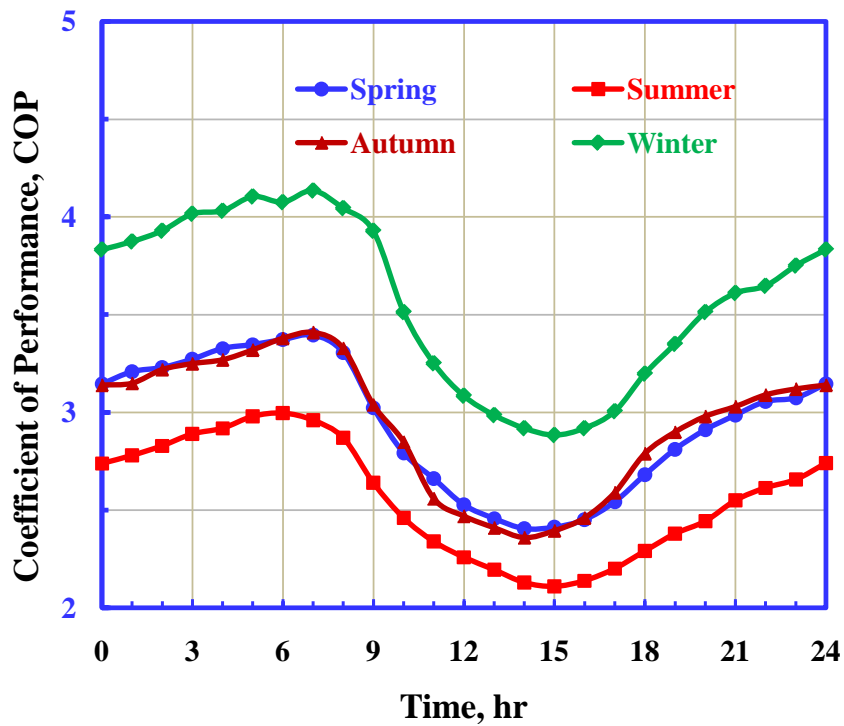

Figure 11. Hourly COP of refrigeration machine. 


\section{Electricity Tariffs}

The thermal storage system is suggested to store the cooling capacity for later use at peak hours. There are two main operating strategies, the first is a full load operation and second is a partial load operation [13] [14]. Full load operation strategy, the cooling loads at peak period is supplied by the thermal storage while the chillers operate only at nighttime. In the partial load operation strategy, some chillers and thermal storage are used to supply the building cooling loads in peak periods simultaneously. In this study, the two main operating strategies are used. Firstly, the partial load operation strategy is used to transfer the peak loads to off-peak period. The demand cooling loads at peak are covered partially from thermal storage system and running some chillers. In off-peak period, all chillers running at full capacity and the excess cooling capacity are stored. Secondly, the full load operation strategy is used to transfer the loads peak to off-peak period which the demand cooling loads at peak period are covering from thermal storage only and all chillers off.

The electricity company in Saudi Arabia is supplying the electrical energy with two tariffs. The first tariff is fixed with electromechanical counter and the second tariff is variable with smart digital counter to courage consumers to shift the loads peak to off-peak period as Table 1 .

\section{Demand Cooling Load for Gabal Al Sharashf}

The buildings construction conditions for Gabal Al Sharashfregion are illustrated in Table 2. The demand cooling loads of Gabal Al Sharashf inside the central zone of Makkah city is calculated with data in Table 2 according to the buildings model $\mathrm{A}$ and floors number. So, the obtained cooling capacity is $180,000 \mathrm{TR}$, and it is used as a maximum cooling load to find the demand cooling

Table 1. Electricity tariffs for contracted customers above $1000 \mathrm{KVA}$.

\begin{tabular}{|c|c|c|c|c|}
\hline \multirow{2}{*}{ Consumption period } & \multicolumn{2}{|c|}{$\begin{array}{l}\text { Electromechanical } \\
\text { counter }\end{array}$} & \multicolumn{2}{|c|}{ Smart digital counter } \\
\hline & Period & $\begin{array}{l}\text { Tariff, } \\
\$ / \mathrm{kWh}\end{array}$ & Period & $\begin{array}{l}\text { Tariff, } \\
\$ / \mathrm{kWh}\end{array}$ \\
\hline \multirow[t]{2}{*}{$1^{\text {st }}$ October-31 April } & 24 hours & 0.0373 & 24 hours & 0.0373 \\
\hline & & & $\begin{array}{c}\text { Saturday } \rightarrow \text { Thursday } \\
\text { 00:00 AM } \rightarrow \text { 08:00 AM } \\
\text { Friday (Weekend)* } \\
00: 00 \mathrm{AM} \rightarrow 09: 00 \mathrm{AM} \\
21: 00 \mathrm{PM} \rightarrow 00: 00 \mathrm{AM}\end{array}$ & 0.0267 \\
\hline \multirow{2}{*}{$1^{\text {st }}$ May-31 September } & & & $\begin{array}{c}\text { Peak period } \\
\text { Saturday } \rightarrow \text { Thursday } \\
\text { 12:00 PM } \rightarrow \text { 17:00 PM }\end{array}$ & 0.0693 \\
\hline & & & Off-peak period & 0.04 \\
\hline
\end{tabular}

United State Dollar, USD, \$ and Saudi Arabia Riyal, SAR: Currency, 1 USD, $\$=3.75155$ SAR. ${ }^{*}$ Friday in Saudi Arabia is the week end holiday. 
Table 2. Construction conditions for Gabal Al Sharashf region.

\begin{tabular}{|c|c|c|c|c|c|c|c|}
\hline \multirow[b]{2}{*}{ Using } & \multicolumn{2}{|c|}{ Land area } & \multicolumn{2}{|c|}{ Construction area } & \multicolumn{3}{|c|}{ Demand cooling load } \\
\hline & $\mathrm{m}^{2}$ & $\%$ & $\mathrm{~m}^{2}$ & $\%$ & Floors No. & $\begin{array}{l}\mathrm{m}^{2} / \\
\mathrm{TR}\end{array}$ & TR \\
\hline Residence & 236,782 & 14.5 & $1,099,122$ & 23.8 & 5 & 29 & 37,901 \\
\hline $\begin{array}{l}\text { Commercial } \\
\text { residence }\end{array}$ & 406,794 & 24.9 & $2,513,579$ & 54.3 & 6 & 30 & 83,786 \\
\hline Residence seasonal & 140,148 & 8.6 & 539,464 & 11.7 & 4 & 28 & 19,267 \\
\hline Commercial & 78,105 & 4.8 & 416,867 & 9.0 & 5 & 29 & 14,375 \\
\hline Educational service & 47,726 & 2.9 & 32,124 & 0.7 & 1 & 7.5 & 4283 \\
\hline Healthy service & 18,977 & 1.2 & 12,410 & 0.3 & 1 & 7.5 & 1655 \\
\hline Religion service & 19,470 & 1.2 & 12,649 & 0.3 & 1 & 7.5 & 1687 \\
\hline Policy service & 952 & 0.1 & 952 & 0.02 & 1 & 7.5 & 127 \\
\hline Green Area & 125,790 & 7.7 & & & & & \\
\hline Streets & 559,201 & 34.2 & & & & & \\
\hline Total & $1,633,946$ & 100 & $4,627,167$ & 100 & & & 163,079 \\
\hline $\begin{array}{l}\text { Assume safety } \\
\text { factor of } 10 \%\end{array}$ & \multicolumn{4}{|c|}{ Total demand cooling load } & \multicolumn{3}{|c|}{$180,000 \mathrm{TR}$} \\
\hline
\end{tabular}

loads profile through 24 hours. The hourly demand refrigeration capacity and compressor consumed power for maximum cooling load of 180,000 TR are estimated for conducting the scenarios of transferring the loads peak to off-peak period.

\section{Shifting Loads Peak Scenarios}

The scenarios of shifting loads peak to off-peak period are depend on the rated chillers capacity and thermal storage tank size. We assumed that the thermal storage tank size is enough to store the excess refrigeration capacity of chillers during off-peak period. The scenarios used to shifting loads peak period are how we decrease the load peak to minimum value to achieve the maximum saving in consumed power and minimum cost of electricity bills. The first scenario is conducted for rated chillers capacity of 180,000 TR which is equal the maximum demand cooling load at 16:00 o'clock. Figure 12 and Figure 13 show the scenario of shifting load peak from 12:00 to 17:00 o'clock in summer which $25 \%$ only of rated chillers capacity is running and other chillers off. The consumed power is decreased by $6.86 \%$ and the saving of electricity bills are $16.66 \%$. Figures 14-17 show the scenario of shifting loads peak from 11:00 to 18:00 o'clock in spring and autumn which $17 \%$ only of rated chillers capacity are running and other chillers off. The consumed power is decreased by $8.54 \%$ and the saving of electricity bills are $12.55 \%$. Figure 18 and Figure 19 show the scenario of shifting loads peak from 11:00 to 20:00 o'clock in winter which $100 \%$ of rated chillers capacity off. Both the decreasing in consumed power and the saving of electricity bills are $14.55 \%$. 


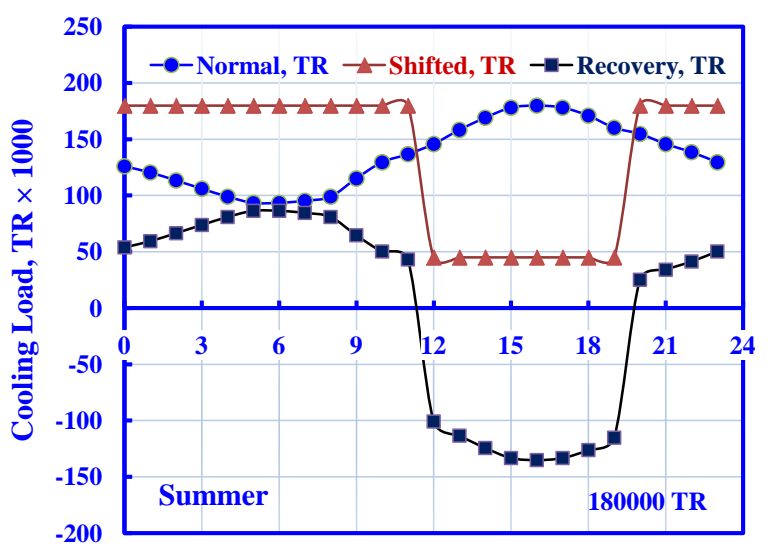

Time, hr

Figure 12. Summer scenario of cooling load for capacity of 180,000 TR.

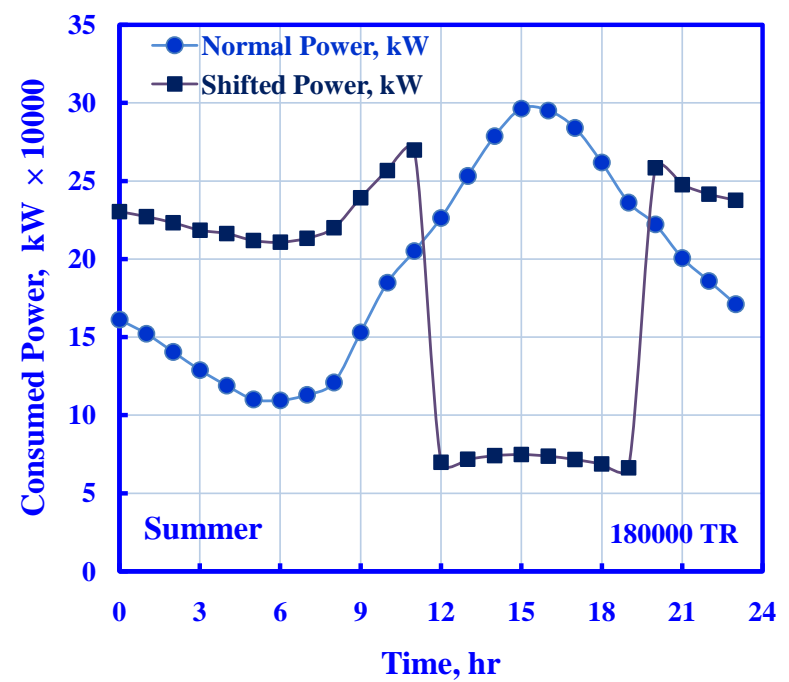

Figure 13. Summer scenario of consumed power for capacity of 180,000 TR.

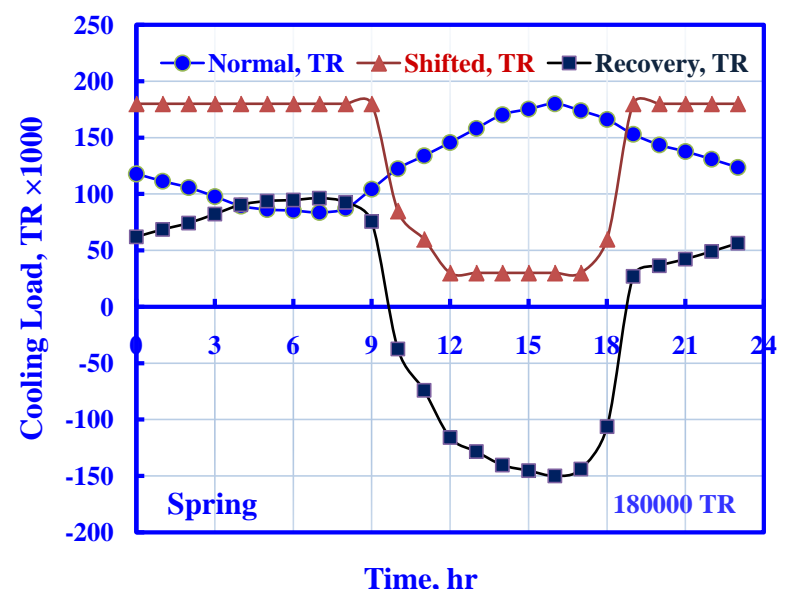

Figure 14. Spring scenario of cooling load for capacity of 180,000 TR. 


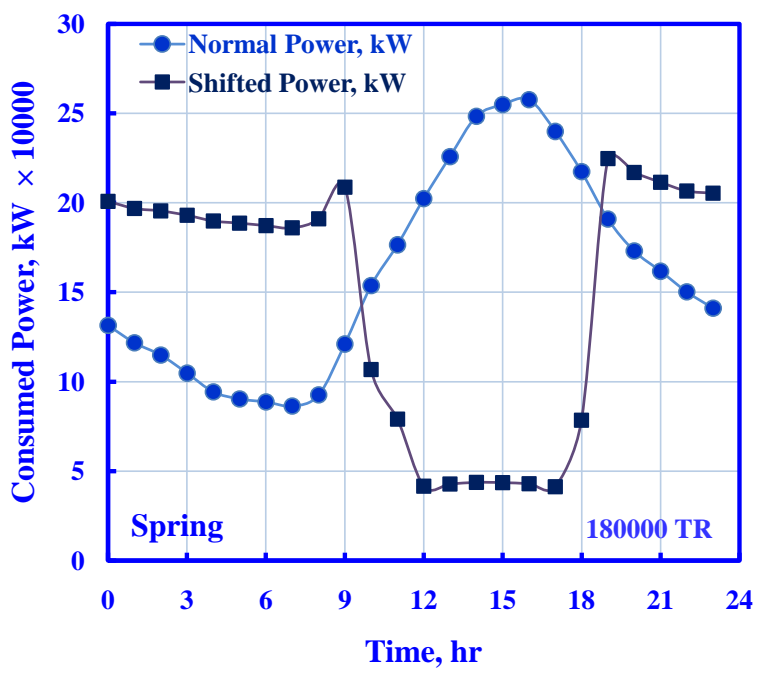

Figure 15. Spring scenario of consumed power for capacity of $180,000 \mathrm{TR}$.

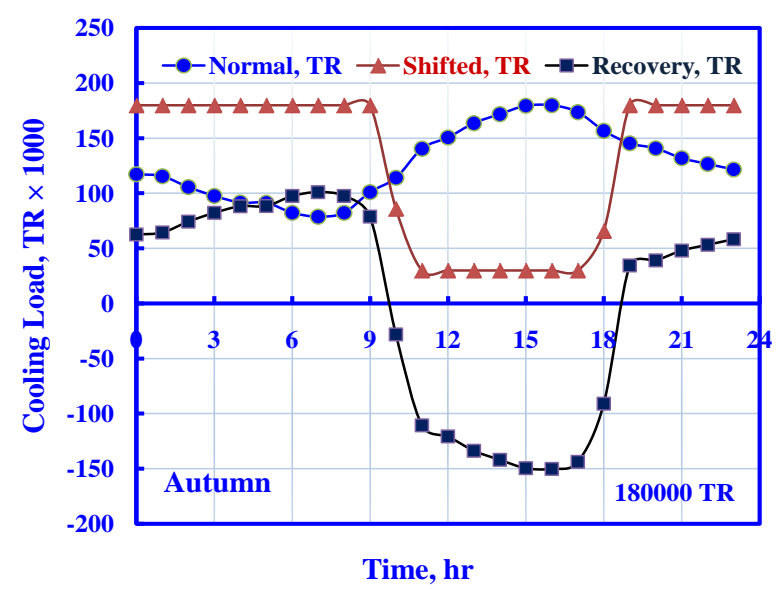

Figure 16. Autumn scenario of cooling load for capacity of 180,000 TR.

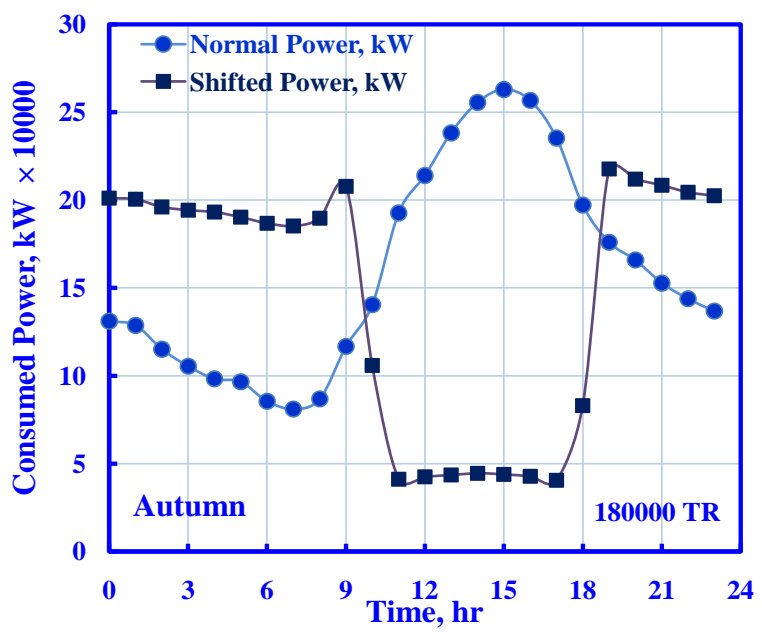

Figure 17. Autumn scenario of consumed power for capacity of 180,000 TR. 


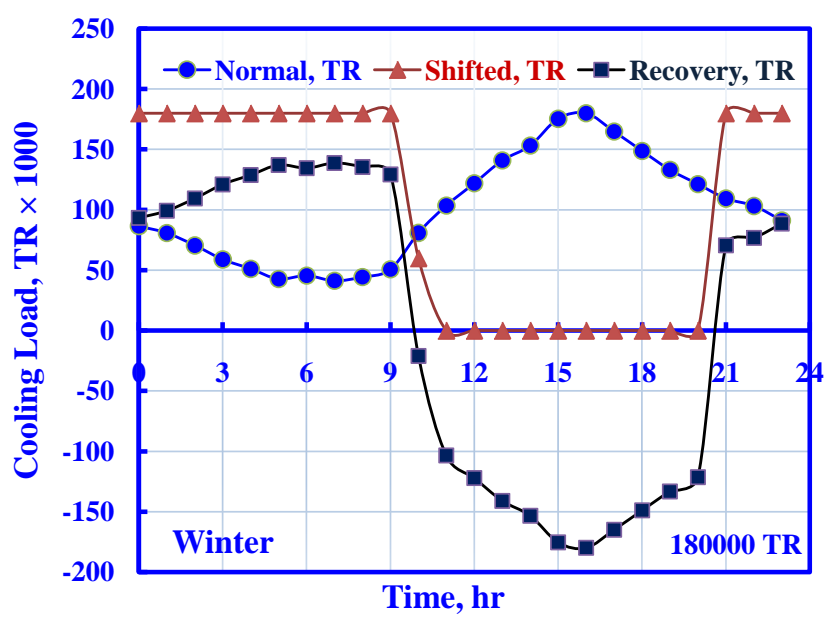

Figure 18. Winter scenario of cooling load for capacity of 180,000 TR.

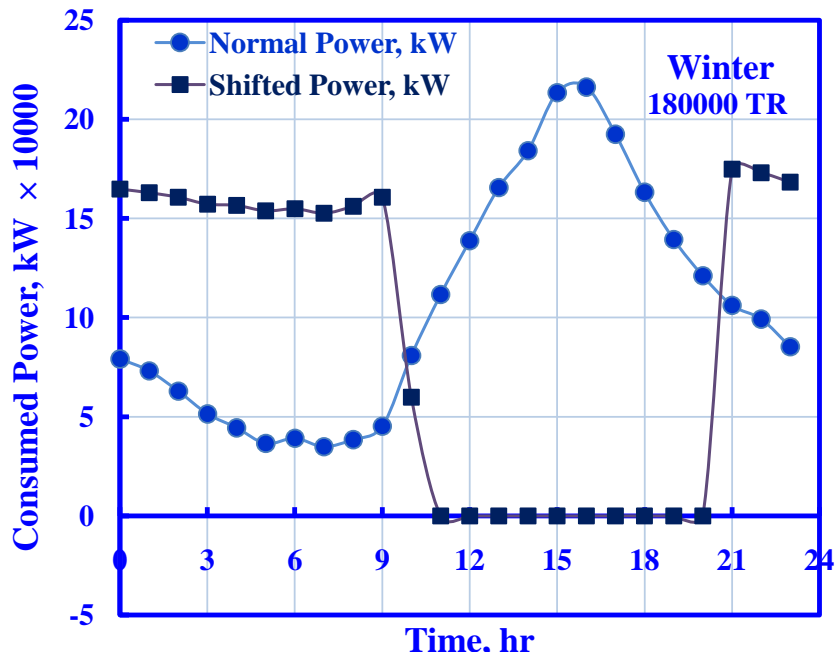

Figure 19. Winter scenario of consumed power for capacity of $180,000 \mathrm{TR}$.

The other scenarios are conducted by increasing the rated chillers capacity to transfer the peak loads to off-peak period, full load operation strategy. Because the discount of electricity cost is available from $1^{\text {st }}$ of May to end of September. We will show some scenarios of summer with various rated chillers capacity as shown in Figures 20-23.

The rated chillers capacity is increased by $11 \%$ up to $122 \%$ with constant cooling load demand profile to investigate the maximum saving in consumed power and minimum cost of electricity bills as summarized in Table 3 . The aim of increasing the rated chillers capacity in the plant is to transfer the loads peak to zero loads and extend the zero loads period gradually to minimize the consumed power and electricity bills as shown in Figure 24 and Figure 25. The increase in saving of consumed power in spring, summer and autumn is dominant than winter because the demand cooling load is low in winter. Also, the increase 


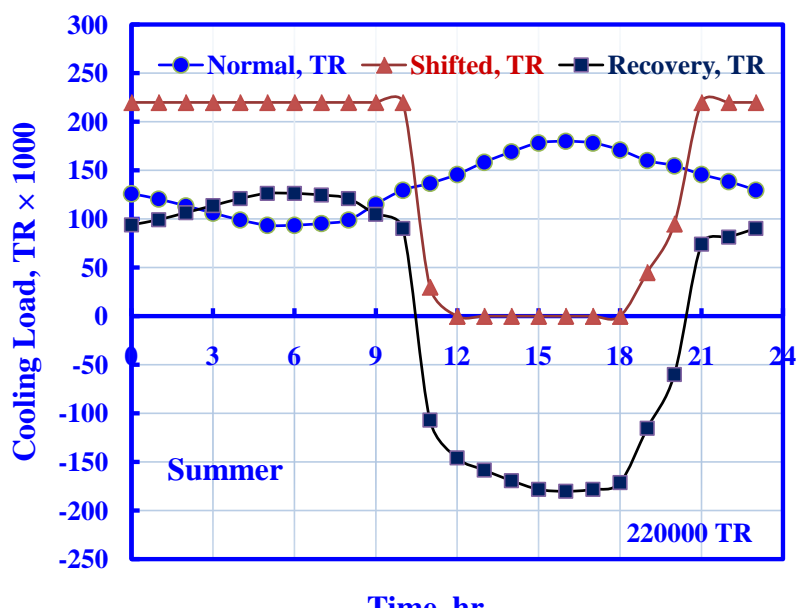

Time, hr

Figure 20. Summer scenario of cooling load capacity of 220,000 TR.

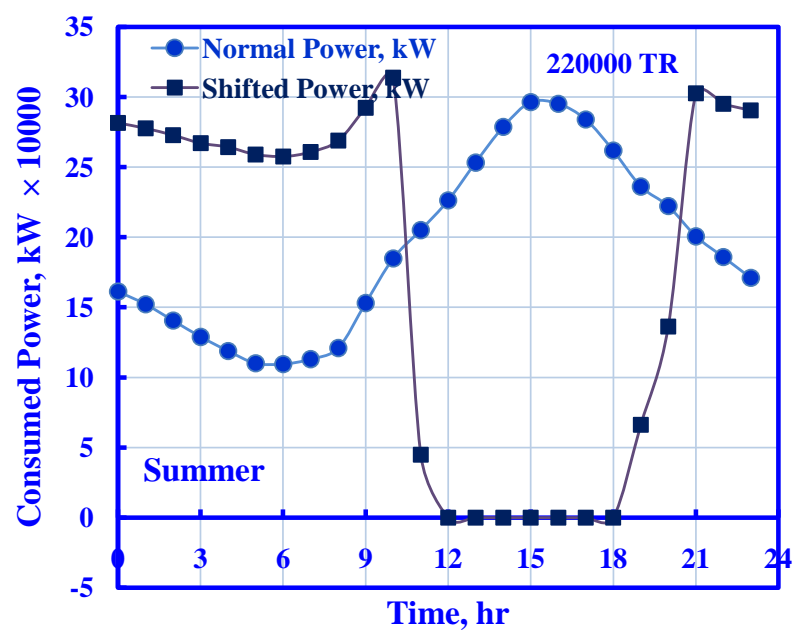

Figure 21. Summer scenario of consumed power for capacity of $220,000 \mathrm{TR}$.

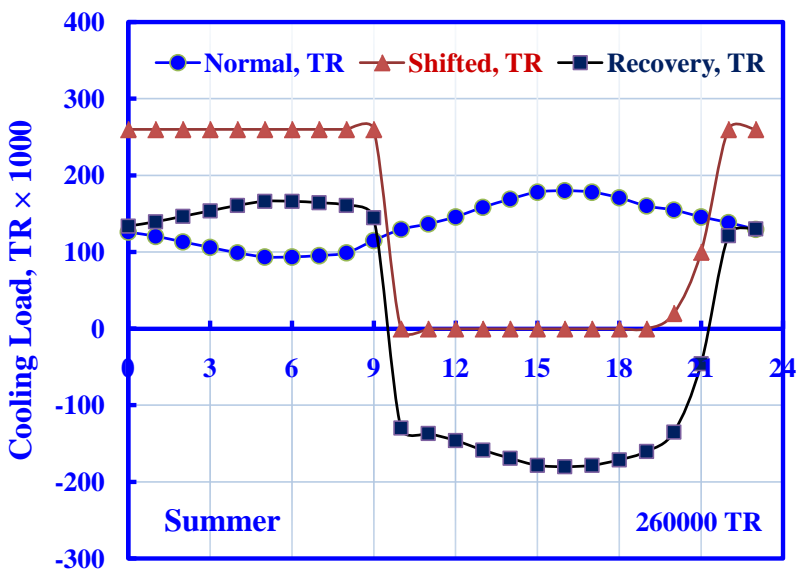

Time, hr

Figure 22. Summer scenario of cooling load for capacity of 260,000 TR. 


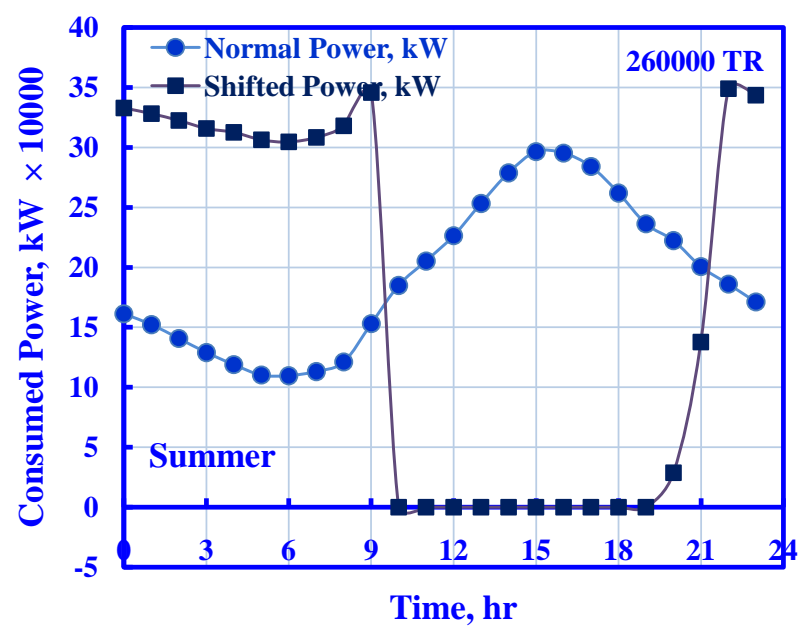

Figure 23. Summer scenario of consumed power for capacity of $260,000 \mathrm{TR}$.

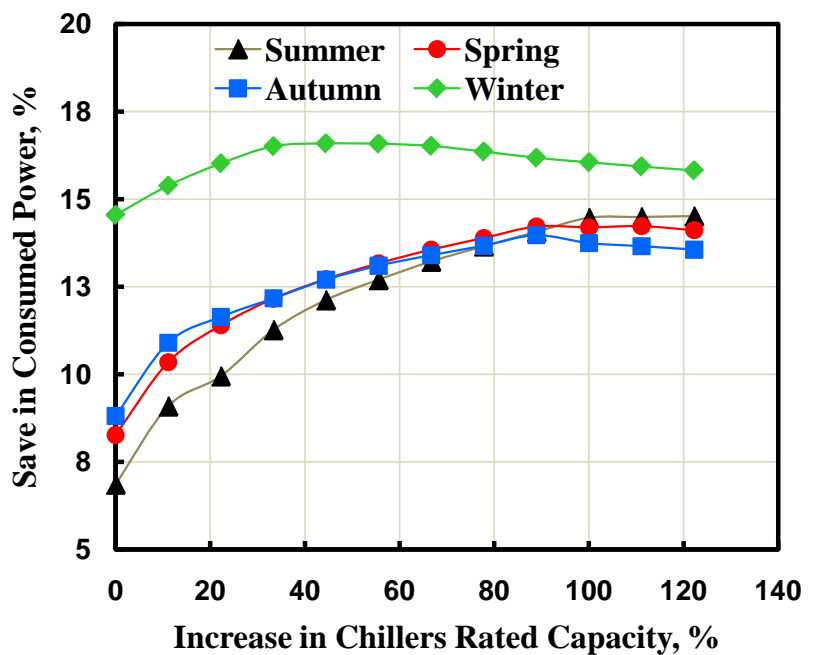

Figure 24. Save in consumed power.

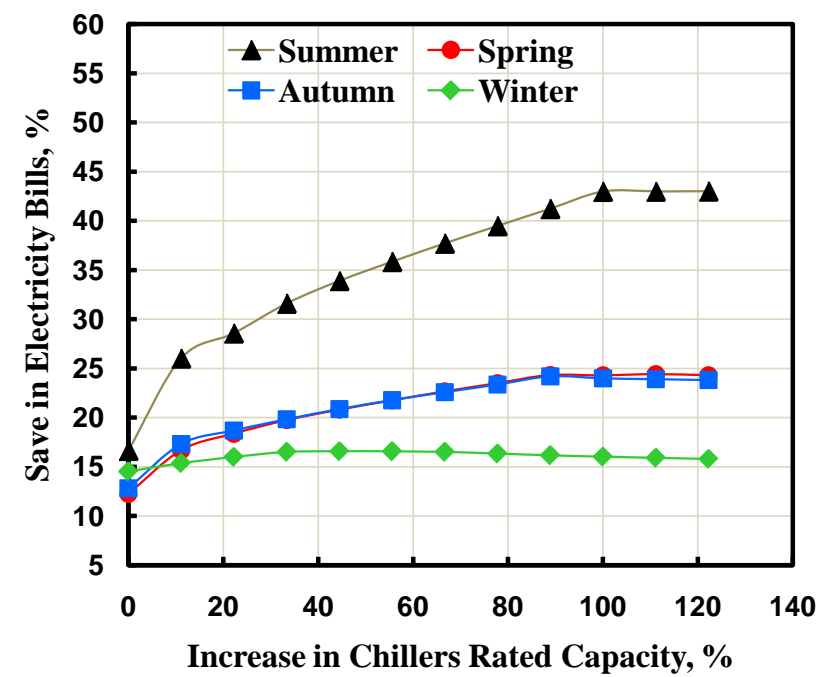

Figure 25. Save in electricity bills cost. 
Table 3. Saving in consumed power and electricity bills cost.

\begin{tabular}{ccccccccccc}
\hline \multicolumn{2}{c}{ Chillers capacity needed } & \multicolumn{3}{c}{ Saving in consumed power, $\%$} & \multicolumn{5}{c}{ Saving in electricity bills, \% } \\
\hline $\begin{array}{c}\text { Chillers rated } \\
\text { capacity, TR }\end{array}$ & $\begin{array}{c}\text { Increase in chillers } \\
\text { capacity } \%\end{array}$ & Summer & Spring & Autumn & Winter & Summer & Spring & Autumn & Winter \\
\hline 180,000 & 0 & 6.86 & 8.27 & 8.81 & 14.55 & 16.66 & 12.26 & 12.84 & 14.55 \\
200,000 & 11 & 9.09 & 10.35 & 10.90 & 15.39 & 26.04 & 16.71 & 17.33 & 15.39 \\
220,000 & 22 & 9.95 & 11.40 & 11.64 & 16.02 & 28.59 & 18.38 & 18.70 & 16.02 \\
240,000 & 11.27 & 12.16 & 12.17 & 16.51 & 31.61 & 19.77 & 19.85 & 16.51 \\
260,000 & 13 & 12.12 & 12.72 & 12.70 & 16.59 & 33.92 & 20.83 & 20.88 & 16.59 \\
280,000 & 44 & 12.70 & 13.17 & 13.10 & 16.58 & 35.86 & 21.78 & 21.79 & 16.58 \\
300,000 & 56 & 13.22 & 13.56 & 13.40 & 16.52 & 37.71 & 22.67 & 22.61 & 16.52 \\
320,000 & 67 & 13.66 & 13.89 & 13.67 & 16.36 & 39.49 & 23.51 & 23.38 & 16.36 \\
340,000 & 78 & 14.07 & 14.22 & 13.97 & 16.18 & 41.24 & 24.34 & 24.20 & 16.18 \\
360,000 & 89 & 14.47 & 14.20 & 13.75 & 16.05 & 42.98 & 24.31 & 24.00 & 16.05 \\
380,000 & 100 & 14.49 & 14.23 & 13.66 & 15.93 & 43.00 & 24.43 & 23.92 & 15.93 \\
400,000 & 111 & 14.52 & 14.12 & 13.56 & 15.82 & 43.01 & 24.33 & 23.84 & 15.82 \\
\hline
\end{tabular}

in saving of electricity bills in summer is dominant than spring, autumn and winter because the electricity tariff during off-peak period is cheap. The importance of data in Table 3 and Figure 24 and Figure 25 are for economic analysis and payback period for minimize the rated chillers capacity needed and thermal storage tank size. Payback Period is defined as the length of time required to recover an initial investment through cash flows generated by the investment. The Payback Period gives the level of profitability of an investment in relation to time. The shorter the period is the better the investment opportunity [10]. The payback period of initial investment of the system is not our interest in this paper.

\section{Conclusion}

A simulation of district cooling plant is performed. Shifting the load peak to off-peak period is recommended with thermal storage system. A model of residence buildings and schools is used to estimate the daily cooling load profile in Makkah, Saudi Arabia at latitude of $21.42^{\circ}$ and longitude of $39.83^{\circ}$. District cooling plant of 180,000 Ton of Refrigeration is suggested to serve the Gabal Al Sharashf area in central zone at Makkah. Fixed electricity tariff is $0.04 \$ / \mathrm{kWh}$ for electromechanical counter, and $0.0267,0.04,0.0693 \$ / \mathrm{kWh}$ for shifting loads peak for smart digital counter. The results showed that the savings in consumed power are $8.27 \%$ in spring, $6.86 \%$ in summer, $8.81 \%$ in autumn, and $14.55 \%$ in winter. But, the savings in electricity bills are $12.26 \%$ in spring, $16.66 \%$ in summer, $12.84 \%$ in autumn, and $14.55 \%$ in winter. The obtained maximum saving in consumed power is $14.5 \%$ and the saving in electricity bills is $43 \%$ in summer when transferring the loads peak to off-peak period. 


\section{References}

[1] Chow, T.T., et al. (2004) Applying District-Cooling Technology in Hong Kong. Applied Energy, 79, 275-289.

[2] Augusto, G.L., et al. (2013) Identification of Design Criteria for District Cooling Distribution Network. Philippine Science Letters, 6.

[3] Bin Shafar, A. (2011) Exclusive Interview of Empower CEO, Ahmad Bin Shafar by Michael Palmer. Dubai UAE.

[4] Lo, A., et al. (2014) Challenges of District Cooling System (DCS) Implementation in Hong Kong. World SB 14, Barcelona.

[5] Chow, T.-T., et al. (2006) Performance Evaluation of District Cooling Plant with Icestorage. Energy, 31, 2750-2762.

[6] Hossain, M.K. (2004) Ice Slurry Storage System in District Cooling Applications for Air Conditioning. Master's Thesis, National University of Singapore, Singapore.

[7] Bahnfleth, W.P. and Joyce, W.S. Energy Use in District Cooling System with Stratified Chilled-Water Storage. ASHRAE Transactions: Symposia, No. 94-32-4.

[8] Beagley, S. (1999) A Chilled Water Storage System as Part of an Energy Management System. Facilities Management Division Northern Territory University, Darwin NT 0909, Australia. http://www.ntu.edu.au

[9] Lin, W.-M., et al. (2015) Optimal Energy Reduction Schedules for Ice Storage Air-Conditioning Systems. Energies, 8, 10504-10521. https://doi.org/10.3390/en80910504

[10] Noranai, Z. and MdYusof, M.Z. (2011) Economical Analysis of Thermal Energy Storage by Partially Operation. Int. J. Mechanical, Aerospace, Industrial, Mechatronic and Manufacturing Engineering, 5.

[11] ASHRAE Fundamentals Handbook, SI, Chapter 27, 1997.

[12] Department of Mechanical Engineering, Technical University of Denmark, Nils Koppels Allé, Building402, DK-2800 Kgs. Lyngby, DENMARK, 2001. http://www.en.ipu.dk/Indhold/refrigeration-and-energy-technology/downloads.asp $\underline{\mathrm{x}}$

[13] Dincer, I. (2004) Thermal Energy Storage. Encyclopedia of Energy, 6, 14.

[14] Habeebullah, B.A. (2006) Economic Feasibility of Thermal Energy Storage Systems: Application to Al-Haram Grand Holy Mosque Air Conditioning Plant. JKAU: Eng. Sci., 16, 55-82. 
Submit or recommend next manuscript to SCIRP and we will provide best service for you:

Accepting pre-submission inquiries through Email, Facebook, LinkedIn, Twitter, etc. A wide selection of journals (inclusive of 9 subjects, more than 200 journals)

Providing 24-hour high-quality service

User-friendly online submission system

Fair and swift peer-review system

Efficient typesetting and proofreading procedure

Display of the result of downloads and visits, as well as the number of cited articles Maximum dissemination of your research work

Submit your manuscript at: http://papersubmission.scirp.org/

Or contact jectc@scirp.org 